\title{
An assessment of a tropical urban stream using benthic macroinvertebrates as a bio-indicator in Muara Angke, Jakarta, Indonesia
}

\author{
CHRISTOPHER KELLY ${ }^{1, \vartheta}$, TATANG MITRASETIA ${ }^{2, \bullet \bullet, ~ J I T O ~ S U G A R D J I T O ~}{ }^{3, \vee \vee v}$ \\ ${ }^{1}$ Kings College. Strand, London WC2R 2LS, London, United Kingdom. "email: chris.kellyy@ gmail.com \\ ${ }^{2}$ Faculty of Biology, Universitas Nasional. Ps. Minggu, Jakarta Selatan 12520, Jakarta, Indonesia. "*email: tatang248@ gmail.com \\ ${ }^{3}$ Centre for Sustainable Energy and Resources Management, Universitas Nasional. Ps. Minggu, Jakarta Selatan 12520, Jakarta, Indonesia. "email: \\ sugar@unas.ac.id
}

Manuscript received: 31 August 2016. Revision accepted: 28 June 2017

\begin{abstract}
Kelly C, Mitrasetia T, Sugardjito J. 2017. An assessment of a tropical urban stream using benthic macroinvertebrates as a bio-indicator in Muara Angke, Jakarta, Indonesia. Bonorowo Wetlands 7: 65-73. A preliminary study was conducted on the populations, density, and distributions of benthic macroinvertebrate species along the course of the Ciliwung/Angke River, Jakarta. The selected river section is highly urbanized and heavily polluted, and five study sites were selected along its course to assess the health of the river ecosystem. Benthic macroinvertebrates are used as a bio-indicator for the evaluation of ecosystem health. Their different pollution sensitivities, wide distribution, and relatively sedentary lives make them valuable candidates for this role. The focal point of the study is the Muara Angke mangrove forest and wetland, a small remnant wetland at the mouth of the river in Jakarta Metropolitan. A comparison is drawn between the different study sites to assess this unique habitat's health and potential utility. Despite several intense pressures resulting from the highly urbanized surroundings, and the mangrove's position at the mouth of the river where pollution accumulation would be highest, the data collected from this site showed a macroinvertebrate population dominated by pollution -sensitive taxa, suggesting the mangrove itself continues to provide significant ecosystem services in water -purification.
\end{abstract}

Keywords: Biological filter, urban wetland, ecosystems services, benthic macroinvertebrates

\section{INTRODUCTION}

At the margins of the land, mangrove habitat has long been recognized as a critical component of nutrient transfer and species movement across large eco-regions. They have been identified as cornerstone ecosystems, supporting healthy functioning in other habitats through the food web (Mastaller 1997). It has been demonstrated in numerous simulation studies that coastal wetland plants are capable of absorbing excess phosphates, nitrates, and other organic materials, helping to prevent eutrophication of watercourses and the asphyxiation of downstream biotic communities (Wong et al. 1997; Chu et al. 1998; Tilley et al. 2002). This is crucial for rivers receiving high levels of organic waste, particularly downstream from large-scale agriculture operations that use excessive nitrate and phosphate loading to increase yields. However, the nutrient load entering mangroves often exceeds wetland plant growth requirements, and other biological filtering mechanisms are also essential factors (Ye et al. 2001).

It is not only sedentary mangrove species that depend on coastal wetlands. Studies have demonstrated that many fish species rely on mangroves to provide a nursery habitat for their juveniles (Sasekumar et al. 1992). Many migratory birds visit these rich environments for food and shelter (Giesen et al., 2007). This makes coastal wetlands vital ecosystems in the regional context, yet applying this knowledge to coastal development in the Jakarta Metropolitan area is worryingly under-developed. In recent years, extreme degradations in Jakarta-bay's marine and coastal habitats have been observed, an ecologically and commercially significant area. Reductions in size and health of coastal wetlands have already begun to undermine several key processes outlined above and precipitated the decline of numerous species which rely on the mangrove. Perhaps most critical for this study is the ongoing reduction in commercial marine stocks. Not only do several key fish, shrimp, and mollusk species depend on mangrove habitat for at least one part of their life cycle (Burhanuddin 1993), they also depend on nutrients carried downstream from Java's fertile volcanic highlands passing through coastal wetlands (Ligtvoet et al. 1996). A robust coastal wetland has the potential to support several commercial operations for Indonesia's citizens, but this potential remains unrealized (Supartono et al., 2016).

This preliminary study investigates the influence of a unique urban wetland on regulating the water quality of a highly degraded urban stream and terrestrial-marine interactions more generally in one of the world's largest coastal metropolitan areas. The diversity, abundance, and community composition of benthic macroinvertebrates relative to wetland proximity were used to indicate overall ecosystem health and vigor in the Ciliwung-/Angke river. The ultimate purpose of this study is to appraise the immense value of one of Jakarta's remaining natural habitats in the hope of preserving its critical function in the face of otherwise unmitigated developmental pressures. The focus of this study will be the Muara Angke wetland, 
170 hectares of remnant mangrove and wetlands which once dominated the Jakarta Bay, now serving as the city's last line of defense against coastal flooding and providing a home for several rare species (Palupi 2007). The role of coastal wetlands in mitigating Jakarta's Perennial flood crises has been well documented (Aerts et al. 2009; Firdaus 2013), particularly as a vital hydrological sink for the city's many rivers. Despite this, the size of the protected wetland area has continually been reduced from more than 1300 hectares due to population and developmental pressures (Nur et al. 2001).

\section{MATERIALS AND METHODS}

The study took place across five main sites along the course of the Ciliwung river, with varying degrees of proximity to the coastal wetland (Figure1). Since we are concerned with the impact of the Muara Angke Wetland on water quality being discharged into the Jakarta Bay and in the lower reaches of the river, and not to the effects of urbanized spaces on less contaminated upstream flows, the first samples will be collected from sites in densely urbanized areas representing the most significant anthropogenic influences on faunal community abundance and composition. From here, our five study sites will be divided into three groups based on their proximity to the wetland and surrounding land -use types to allow for both inter and intra-group comparisons where relevant.

This study uses sampled measurements of benthic macroinvertebrate community composition and density to indicate water quality and establish the significance of the remaining wetland area's bio-filter effect. This method has been employed in several previous studies worldwide (Rosenberg and Resh 1993; Adakole and Annune 2003; Diaz et al. 2013).

Benthic macroinvertebrates make excellent study specimens, being numerically abundant, readily collected and surveyed, comparatively easy to identify, and taxonomically rich (Dodson 2001). Most benthic macroinvertebrates, particularly in their larval stages, are also relatively sedentary, unable to quickly relocate, and displaying any effects of localized environmental conditions (Cairns and Prall 1993). In addition, bio-indication using benthic macro-invertebrates gives a clearer picture of water quality over time, mainly but limited to the life-cycles of identified species, which is reflected in the distribution and diversity of pollution sensitive versus pollution tolerant communities (Warwick 1993).

A total of 435 samples were taken across all study sites over four weeks period June - July 2015. Initially, it had been planned to take three samples per day at each site, but this was increased to six to reduce overall study length when slight daily variation in results was observed during the first weeks of collecting data. Instead, the six daily samples would be taken at several different specific locations surrounding each study site in an attempt to capture any spatial variation in benthic species distribution within a given area.

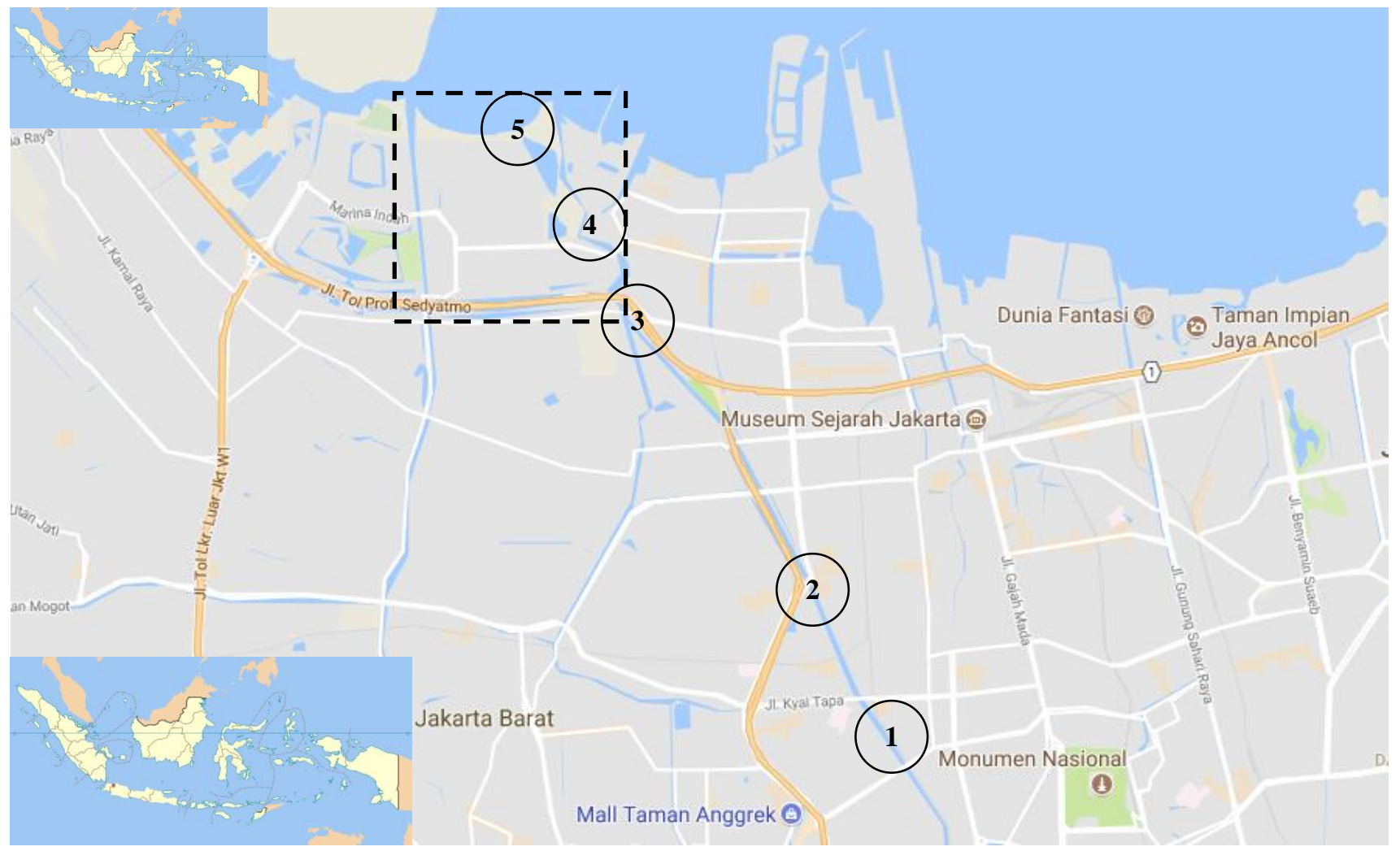

Figure 1. Situation map of Muara Angke, Jakarta, Indonesia. Box = Location of protected wetland (Muara Angke Wildlife Sanctuary) 
Sampling methods involved basic disturbance sampling of river bed substrate and collection using a standard kick net. It is important to note that, due to river banks' unstable or otherwise hazardous conditions, including the build-up of highly soft and deep sediment at the waters' edge, samples were almost universally collected within two meters of the bank with deeper water samples collected where possible. Given the spatial distribution of different species throughout the benthic habitat, it is recognized that this may affect the validity of the results. Therefore, future studies may wish to employ boats or floating platforms to gather samples over a wider area.

The substrate was disturbed for thirty seconds at various points within each study site, with net contents emptied into a sample tray, spread evenly, and analyzed on-site in the field using a magnifying glass. In order to account for human error in species identification and counting, scrutiny of any given sample was limited to five minutes, or until satisfied that there were no further specimens to identify in that sample. It is also important to note that counts for a single species were capped at 50 in a given sample due to issues with counting large numbers of individuals accurately. Species were identified as precisely as possible, including considering the specific life-stage (i.e., larvae, pupae, adult). For analysis, the taxonomic group of collected specimens was deemed sufficient to conclude bio-indication given many different groups monitored and the practical difficulties of precise species identification in the field (Hodkinson and Jackson 2005).

\section{Study areas}

The main factor dictating the selection of specific sample sites was the ease of access. Large stretches of the river have artificial concrete banks that make access to the river bed extremely difficult. In the interests of safety, these areas were avoided in favor of sites where water access was possible on foot. To include a range of different circumstances influencing water quality and species community composition, sites were also selected to incorporate various nearby human activities and land uses. These sites were then grouped to reflect similarities in habitat conditions as follows: (i) Group 1 - 'Highly Urbanized' (sites 1 and 2) ; (ii) Group 2 - 'Transition Areas' (sites 3 and 4) ; (iii) Group 3 - 'Wetland Influenced' (site 5).

A brief description of each group and specific study sites is given below.

Group 1 - Highly Urbanized, representing habitats significantly affected by surrounding urban activities. This group experiences little or no influence from natural ecosystems.

Site 1 is called Roxy. It is located near the center of Jakarta's most densely populated area, is named after the adjacent Roxy Mall, and demonstrates a variety of surrounding urban land use types, including major roadways, a large mall parking area, a ground-level train route, a relatively small, informal food market and a mixture of established residential neighborhoods and kampung (Informal, low-income housing). High volumes of plastic waste are evident on the river banks and the water itself. This site represents the most extensive influence of various urban activities on the local benthic ecosystem. It is clearly a highly degraded habitat.

Site 2 is called 'Season City,' located near a major roadway that passes directly over the watercourse and is surrounded by many different settlement types. The urban density in the immediate vicinity is significantly less than further upstream, and the road is also considerably smaller. There is reduced land-use pressure on the river banks at this point, as evidenced by more extensive embankments, and several clusters of trees are growing adjacent to the watercourse.

Group 2 - Transition Areas, representing habitats with an increased natural component. While these sites cannot be labeled wetlands in the true sense, they are influenced by significantly more natural areas and may begin to experience a mild bio-filter effect.

Site 3 was named after Jakarta's airport toll road, which passes over the study site, responsible for converting previous wetlands and the inundation of numerous surrounding areas. At ground level, there is almost a total lack of paved or otherwise wholly impermeable surfaces; instead, the thoroughfares are largely dirt tracks connecting small pockets of informal settlement. The river banks themselves are less crowded with refuse than the sites in group 1. We can expect the numerous pockets of largely inundated green spaces surrounding the river at this stage to absorb some surface contamination, initiating a mild bio-filter effect.

Site 4, named 'Pluit,' lies at the upstream edge of the Muara Angke protected wildlife area. Despite its proximity to the largest intact area of near- pristine wetland, its position on the upstream fringe of this area limits the potential for wetland-derived improvements to local water quality. Furthermore, Site 4 is under greater pressure from local development projects and associated land-use changes than Site 3, which is surrounded by a network of fully paved roads and far more extensive human settlements, including the neighborhood of Muara Angke.

Group 3 - Wetland Influenced. These sites are sufficiently proximate to the remnant or naturalized wetland areas that we expect to see a significant influence of the aforementioned bio-filter effect on the local benthic community. This group is comprised only of site 5 .

Site 5 is positioned just beyond the downstream edge of the Muara Angke Wildlife Protection Area, from which it derives its name. While this site is not within the conservation area itself, where the naturalized state of the wetland would doubtless deliver higher biodiversity, it was selected to provide an insight into the downstream bio-filter effect impact on the water having passed through the mangrove area. While this group contains only one site, it was also selected because it includes both a naturalized and artificially planted wetland area close to where samples can be collected.

We have divided the individuals collected into 3 groups representing those species capable of tolerating high levels of pollution (group 3), somewhat pollution tolerant species 
(group 2), and those species susceptible to pollution and degradation of aquatic habitats (group 1), according to several field guides and previous studies (Swari et al. 2014; Emere and Nasiru 2008; Azrina et al. 2006). This highlights the importance of exactly which species comprise a given ecological community when using bio-indication, in addition to basic abundance and biodiversity analyses. The purpose is to demonstrate a difference in community composition and abundance visually. We use the same primary data for the calculations and multiply the number of individuals by their pollution weighting to give our weighted abundances.

The Shannon Diversity Index (BDI) was calculated for the samples taken each day at all study sites, following Ogbeibu and Oribhabor's study. 2002). Several statistical tests such as Kruskal-Wallis and Mann-Whitney U test were performed on the data collected from the survey to determine the significance of differences between study sites and prove or disprove the stated hypotheses.

\section{RESULTS AND DISCUSSION}

\section{Macroinvertebrate abundance and community composition}

The overall macroinvertebrate abundance and community composition are summarized in table 1 , with different taxa organized by their sensitivity to pollution. A total of 19 taxa were identified from a total sample of 7,168 individuals collected. The number of taxa identified at each site ranges from just 4 at site 1 (Roxy) to 11 at site 5 (Muara Angke), with a steady increase from each site further downstream, as anticipated from the increasing influence of more natural environments at each location. From group 3, we can assume a higher local water quality, perhaps attributed in part to the bio-filter effect, even if the overall biodiversity of species is equal or lower than other sites dominated by pollution tolerant species.

Site 1 displayed significantly lower species abundance and taxonomic diversity than the others (54 individuals, $0.75 \%$ of total). In contrast, recorded species were dominated by segmented worms of the orders Oligochaetae and Hirudinae; both species are known to be highly tolerant to pollution; abundance remained low throughout this study. The presence of fly larva (Muscidae), usually less tolerant of pollution, may be explained by the presence of discarded rotting meat and other organic material from nearby human settlements.

Site 2 saw a marked increase in the abundance and diversity of recorded taxa (239 individuals, 3.33\% of total). Oligochaetae remained the most abundant taxa; however, several similar pollution tolerant species not present at site 1, including Physidaeand Chironomidae (bloodworm), were recorded in significant numbers, increasing the recorded diversity at this site.

The increase in species abundance and recorded taxa between sites 1 and 2 is perhaps a result of the larger surrounding earthen embankments, which may absorb some volume of contaminated run-off and provide a more suitable habitat for colonization. Furthermore, an increase in surrounding vegetation provides a greater organic nutrient input, particularly for Physidae, which are known to graze on decaying leaves (Magee 1993). The lower number of urban pollution sources identified in the immediate area is also likely to result in less degraded habitat. It is worth noting that the presence of a single larva from the family Tipulidae recorded at this site would appear to be anomalous, perhaps indicating that this individual had been dislodged from further upstream. Nevertheless, its impact on the overall trend in this study is minimal, and as such, it has been included in the final data set.

Site 3, the first of the identified 'transition sites' demonstrated a significant increase in invertebrate abundance (1,624 individuals, $22.66 \%$ of total) and a less important but notable increase in the identified taxa from a total of 7 for Sites 1 and 2 (Group 1) to 9 for Site 3 alone. A key factor that may explain this incremental increase in diversity is a similar increase in the variety of available micro-habitats along this stretch of the river, including variations in substrate, light and temperature conditions, and flow velocity. This may allow colonization of different points by new species combinations, and significant spatial heterogeneity was recorded for this study site.

There was an increase in abundance for all taxa recorded at upstream study sites except Hirudinae at site 3 . A dramatic increase in the abundance of Oligochaetae by a factor of more than 7, clearly dominating this habitat. Physidae numbers also increased, and for the first time, Ciroxidae and Noteridae were recorded, indicating a significant increase in the digestible organic material present. This composition is clearly related to the presence of extensive riparian vegetation as compared to sites further upstream, given that each of these taxa is known to consume decaying plant matter (Anderson and Sedell 1979), as well as a build-up of organic and chemical pollutants tolerable to segmented worms in particular.

Unlike Site 3, the recorded abundances for many groups dropped at study site 4 , perhaps attributed to a combination of heavy siltation generating warm, shallow, slow-moving water and the accumulation of upstream pollution sources allowing the remarkably tolerant Oligochaetae to out-compete other species for deposited organic nutrients. The two exceptions include Notonectidae, for which the slow-moving water likely provides a more suitable hunting ground than upstream river stretches, and the earthworms of Lumbricidae, for which the marshy banks and variable watermark permit the easy transition between riparian and newly flooded habitat.

Site 4 also saw a further increase in abundance $(2,429$ individuals, $33.89 \%$ of total), with the Oligochaetae worms cementing their near-total domination of the invertebrate faunal community (over $96 \%$ of recorded individuals). The worm population was very dense at this site. Since many samples contained individuals too numerous to count by hand accurately, they were allocated a count of $50+$, and total population numbers are certainly under-represented.

As expected, site 5 contributed the largest number of individuals $(2,822 ; 39.37 \%$ of total $)$ and the greatest taxa (57.89\% of total). Crucially, the taxonomic composition 
recorded at this location was dominated, overwhelmingly, by species identified as being sensitive to pollution and was unique amongst the 5 study sites in this regard. As identified below, all other sites were dominated by taxa from the 'pollution tolerant' group. Significant is the almost total absence of Oligochaetae worms, the dominant taxa at all other study sites, and their replacement as the dominant taxa by Pachychilidae, gilled snails known to be highly sensitive to pollution (Allen et al. 2012). Atydae comprises, the other significant pollution-sensitive taxa at this site is almost absent from upstream locations. Finally, the presence of predatory larvae, both dragonfly and damselfly from the order Odanata, at site 5 indicates a more complex food web than was identified at Site 1-4, where the majority of species documented were simply detritus feeders.

Species richness was calculated for each study site using the Shannon-Wiener index, and a significant increase was recorded for each site $(27,90.3,541.3,768.1,850.9$, respectively). The recorded individuals are listed by species in table 1 , visualized further in figure 2.

\section{Benthic macroinvertebrate abundance}

An initial Kruskal-Wallis $\mathrm{H}$ test demonstrated a clear statistically significant difference in the abundances of macroinvertebrates recorded at the different study sites ( $\mathrm{x} 2$ (4) $=114.138, \mathrm{p}<0.001)$. The mean rank scores for abundance for study sites $1-5$ were $15.19 ; 44.41 ; 93.71$; 115.66, and 96.03, respectively. To detect the differences in abundances recorded between pairs of study sites, we applied the Mann-Whitney $U$ test. The results show a significant difference for all comparisons $(p<0.001)$ except 3: 5 and 4: 5, where high counts of segmented worms at sites 3 and 4 approached the total individual count at site 5 .

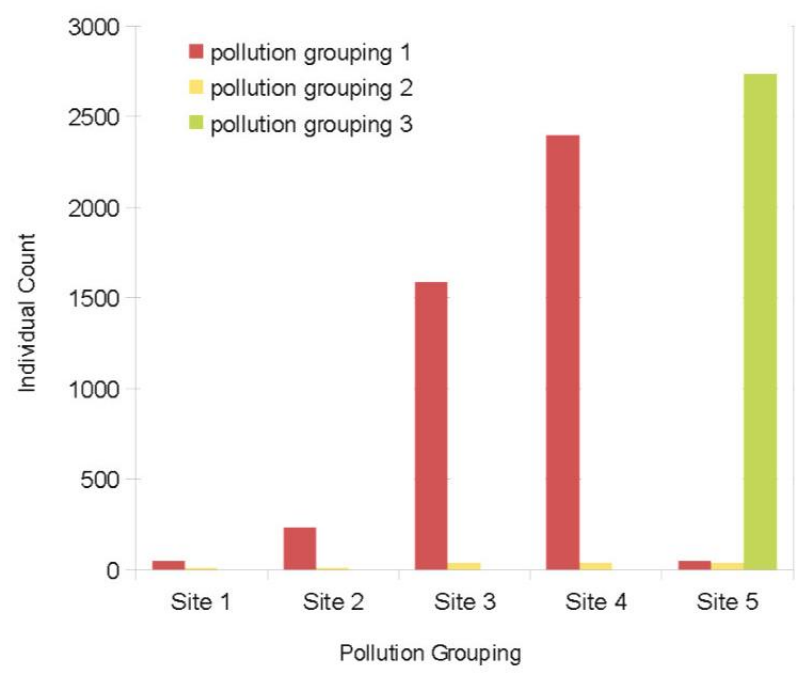

Figure 2. Distribution of individuals recorded taxa based on sensitivity to pollution $(\mathrm{n}=7,168)$

Table 1. List of individuals' family taxa recorded at the study site (in Muara Angke, Jakarta, Indonesia) arranged in accordance to pollution sensitivity

\begin{tabular}{|c|c|c|c|c|c|}
\hline Taxa & Site 1 & Site 2 & Site 3 & Site 4 & Site 5 \\
\hline \multicolumn{6}{|l|}{ Pollution Grouping 1} \\
\hline Physidae (pouch snails) & 0 & 6 & 20 & 8 & 0 \\
\hline Chir onomidae (midges; larvae) & 2 & 12 & 16 & 15 & 0 \\
\hline Chir onomidae (bloodworms) & 0 & 2 & 2 & 0 & 37 \\
\hline Oligochaetae (Aquatic Worms) & 29 & 207 & 1517 & 2340 & 1 \\
\hline hirudinae (Leeches) & 14 & 4 & 1 & 3 & 0 \\
\hline Ciroxidae (Water Boatman) & 0 & 0 & 30 & 15 & 10 \\
\hline Notonectidae (Water Boatmen) & 0 & 0 & 0 & 13 & 0 \\
\hline \multicolumn{6}{|l|}{ Pollution Grouping 2} \\
\hline Muscidae (True Flies; larvae) & 9 & 7 & 22 & 1 & 0 \\
\hline Simuliidae (Black Flies; larvae) & 0 & 0 & 0 & 0 & 0 \\
\hline Noteridae (Beetles; adults; larvae) & 0 & 0 & 15 & 6 & 36 \\
\hline Tipulidae (Crane Flies; larvae) & 0 & 1 & 0 & 0 & 0 \\
\hline Hydrop sychidae (Web-spinning Caddisflies; larvae) & 0 & 0 & 0 & 1 & 0 \\
\hline Lumbricidae (Earthworms) & 0 & 0 & 0 & 27 & 0 \\
\hline Nepidae (Water Scorpion; Ranatra) & 0 & 0 & 0 & 0 & 2 \\
\hline \multicolumn{6}{|l|}{ Pollution Grouping 3} \\
\hline Pachychilidae (Spiral Gilled Snails) & 0 & 0 & 0 & 0 & 2416 \\
\hline Ampullariidae (Apple Gilled Snails) & 0 & 0 & 0 & 0 & 70 \\
\hline Atydae (Shrimp) & 0 & 0 & 1 & 0 & 212 \\
\hline Parathelphusidae (crabs) & 0 & 0 & 0 & 0 & 2 \\
\hline Odanata (Damselfly; larvae) & 0 & 0 & 0 & 0 & 12 \\
\hline Odanata (Dragonfly; larvae) & 0 & 0 & 0 & 0 & 24 \\
\hline Total & 54 & 239 & 1624 & 2429 & 2822 \\
\hline
\end{tabular}


Although these results clearly demonstrate a significant difference between the abundances recorded at upstream sites with the least influence by the wetland and those sites further downstream, the mean rank abundances recorded at sites 3 and 4 were higher than at site 5. Although these results were not statistically significant, the similarities in higher abundances recorded at the 3 furthest downstream sites compared to those upstream suggest that wetland proximity and the presence of river- adjacent green spaces positively influence benthic biotic activity.

\section{Weighted abundances by pollution grouping}

As previously stated, to contextualize subsequent biodiversity analyses, it is important to consider the different pollution sensitivities of recorded species. A dramatic change in community composition favoring species sensitive to water-borne pollution was recorded at site 5, mainly influenced by the surrounding Muara Angke wetland. A subsequent analysis will now be conducted to determine the statistical significance of this change. The weighted abundances show an exaggerated increase in species count at site 5 compared with the abundances recorded in figure 3, which was expected given the dominance of pollution-sensitive species in that area. These test results display a greater, more significant difference between the study sites ( $\mathrm{p}<0.001$ for all comparisons) and, crucially, exaggerate the differences between sites 3,4 , and 5 because of the different weightings assigned to the species found there. This is important for this study because pollution sensitive species are more significant indicators of ecosystem health, and the distortion of our initial findings when pollution weightings are applied has increased our weighted abundances by a greater factor at each successive downstream study site when compared to the results before pollution sensitivity is accounted for.

\section{Species diversity}

As outlined in our preliminary analysis, the recorded species richness increased with each site close to the Muara Angke wetland. Still, due to the domination of specific taxonomic groups, a subsequent biodiversity analysis will be conducted to give a more accurate picture of the relationship between wetland proximity and biotic diversity at each site. Initial Kruskal-Wallis $H$ test analysis demonstrated a clearly significant difference in Shannon Biodiversity Index rating between the 5 study sites: $\mathrm{x} 2(4)=$ $31.04, \mathrm{p}<0.001$, with mean ranks of $58.03 ; 87.67 ; 61.02$; 54.50 and 103.78 for sites $1-5$, respectively.

To determine the significant differences between individual study sites and to enable a direct comparison, a Mann-Whitney U test was performed on the Shannon BDI results for paired site results. The results indicate the most significant differences in biodiversity can be found when comparing sites 3 and 4 to study site 5 , with lower counts of fewer species accountable for the statistical insignificance recorded between upstream sites.

The results of the BDI comparison support several points. First of all, the near -total dominance of aquatic worms from the Oligochaetae taxa amongst the collected individuals, particularly at sites 3 and 4, has resulted in a lower BDI rating at these sites despite the higher number of total species recorded there when compared with site 2 , for example. Similarly, the domination of recorded individuals at site 5 by the Pachychilidae gilled snails may explain the lack of significant difference in biodiversity between site 5 and site 2, where the domination by a single species, although present, was far less dramatic.

\section{Biodiversity by site group}

The five study sites from which samples were collected were placed in 3 groups to reflect similarities in local conditions, wetland proximity, and other factors that affected benthic faunal composition. No significant difference was calculated for the BDI between study site group 1 and study site group 2 ( $\mathrm{U}=1477, \mathrm{p}=0.254$ ), consistent with the observation of low taxonomic diversity across all sites in the watercourse areas upstream of the wetland, where slight variation in species was also recorded. The differences in diversity between study site group 1 and the heavy wetland-influenced site in group 3 were more significant (mean ranks: 4.32, 51.36 respectively; $\mathrm{U}=627.5, \mathrm{p}=0.05$ ). Between-group 2 and group 3, the divergence was even more important (mean ranks: $31.36,65.48$ respectively;, $U=160, \mathrm{p}<0.001)$.

\section{Discussion \\ Species and pollution in the Ciliwung River}

Although the biodiversity analysis results do not fully support the hypothesis that proximity to the wetland correlates with a significantly higher biodiversity rating, they help draw several important conclusions. Namely, it is important to note that the biodiversity ratings at site 5 were consistently higher than at other sites and significantly higher than at sites 3 and 4, which rank second and third in our study for species richness and specimen abundance and share a similar dominance in recorded specimens by a single taxon. Secondly, this significant difference in BDI rating between sites 3 and 4 (group 2) and site 5 (group 3) was recorded despite only a single additional taxon being recorded at site 5, indicating that the benthic macroinvertebrate community itself is more diverse and thus in better ecological health (Schläpfer et al. 1999).

What, then, does this specific composition of invertebrate species and their abundances reveal the water quality of the Ciliwung river system throughout its lower, urbanized reaches, and, importantly, about the role of the Muara Angke Wetland therein? Firstly, it is clear that dividing the study sites into groups as stated in the methodology accurately reflects a degree of physical, chemical, and faunal variation between these groups. The low abundance and diversity recorded at highly urbanized sites clearly indicate the negative impact of numerous urban pollution sources and upstream contributors on overall ecosystem health and functioning. It is important to note that dramatic differences in the size of individuals were also noted, with upstream study sites in group 1 displaying a tendency towards far smaller individuals of the same species than in group 2 . This is likely related to the significant increase in riparian vegetation surrounding these sites, providing edible material for detrital feeders and 
potentially compensating somewhat for the accumulation of pollutants from upstream in supporting a food web based on periphytic algae (Sharma and Rawat 2009). Although this data was not recorded, adequate facilities and time being unavailable, it was nonetheless significant and should be considered when planning subsequent studies.

While differences between group 1 and group 2 study sites were significant, the radical changes in both composition and abundance at study site 5 compared to the other four study sites emphasize the strong influence exerted by the MuaraAngke Wetland system on polluted water, as expected from the results of previous studies included in the literature. Despite variations in a specific composition, invertebrate communities at each of sites 1-4 were dominated by Oligochaetae, a taxon widely known to be remarkably tolerant of high levels of pollution, both organic and anthropogenic, and low oxygen or anoxic stream conditions (Lin and Yo 2008; Azrina et al. 2006). Other groups common at these sites were also found in the 'pollution tolerant' grouping, including Chironomidae, Physidaeand both Ciroxidae and Notonecidae families of water boatman. Of the other taxa recorded at these sites, the vast majority fell into this grouping, with a small number of moderately tolerant taxa also recorded. Many of these species can survive in-stream conditions with very little oxygen, either because they can gather this from the surface or possess other physiological adaptations, suggesting a low dissolved oxygen content in the stream water. This may be a result primarily of organic pollution precipitating algal blooms. However, the near- total dominance of Oligochaetae, exceptionally tolerant to various stressors even amongst this grouping, suggests high inorganic contamination levels were also present. It is important to note that upstream sites recorded almost no species from the 'pollution sensitive' grouping 3, with the sole exception of a single Atydae shrimp at site 3, which would appear on all counts to be an anomalous result.

\section{Biofiltration in and around the Muara Angke Wetland}

Site 5, identified in the study methodology as being heavily influenced by the ecology of the remnant Muara Angke Wetland, possessed a very different taxonomic composition. As is clearly evidenced from a brief overview of the data presented in Table 1 and is further visualized in figure 1 , this study site was dominated almost entirely by taxonomic groups identified as being highly sensitive to pollution-related stressors in the surrounding water. Further analysis of the taxa recorded indicates that this is not simply a result of variations in habitat conditions. Gilled snails (both Pachychilidae and Ampullariidae) identified previously as the dominant group at this site, unlike their cousins, the Pouch Snails, breathe using an aquatic gill system, and depend on high levels of oxygen in the surrounding water, thus making them highly sensitive to both organic and inorganic contaminants (Voshel 2002). Individuals from at least two distinct species were identified at various points around study site 5, suggesting several different ecological niches are available for this pollution-sensitive group of creatures and decreasing the likelihood that their abundance can be explained simply by an unusual surplus of a particular food source, for example. Similarly, the presence of crustacean taxa Atydae and Parathelphusidae, both dependent on gill systems to breathe, indicates an improved water quality given the sensitivities of these species to pollutants, suspended particulates, and oxygen (Harmon 2008).

Despite not being recorded in our dataset, as mentioned previously, it is essential to note that each of these taxa at site 5 displayed considerable variations in size and, by extension, age, with both the largest and some of the smallest individuals collected from any study site being identified within the same species. This was most pronounced amongst the Ampullariidae taxon of gilled snails but also amongst Atydae and the other recorded Mesogastropoda. This clearly indicates a wide range of ages amongst individuals and would suggest that significant pollution levels are not accumulating over time within their bodies, allowing them to reach greater ages than taxa at upstream sites, which are unlikely to survive in highly polluted conditions for as long (Mason 2002). Similarly, identifying predatory species from the taxa Odanatae, and even the more tolerant Nepidae group, indicates that pollution from the surrounding water is not accumulating in sufficient concentrations in the bodies of prey species to be harmful. The increasing concentration of inorganic pollutants through higher levels of the food web has been well documented in a variety of aquatic and terrestrial environments (Farag et al. 1998; Hsu et al. 2007), and such the presence of a more complex food web at this study site can be taken as clear evidence of improved ecosystem health and function.

Finally, it is worth noting that, although the same number of different taxa were identified within the natural wetland area and the adjacent constructed wetland, the abundances of those species were significantly higher at points where the water had also passed through the planted mangroves of the artificial wetland area. This suggests that a combination of natural and constructed wetlands may offer the maximum potential for improving water quality, and thereby ecosystem functioning. Having established the positive influence of the Muara Angke wetland on even the most degraded urban watercourses, follow-up studies should be undertaken to establish the optimal system for wetland-based bio-filtration in this area using a combination of natural and managed or constructed wetland infrastructures.

To summarize, several important conclusions can be drawn from the results discussed above. First of all, despite the methodological limitations of this study, it is clear that the presence of wetland areas has a significant positive impact on the quality of water in the Ciliwung/Angke watershed, even after substantial reductions in the wetland area and the significant degradation of river water from upstream activities and the urban habitat. All indicators identified in the study methodologies (diversity, abundance, size of individuals, and pollution sensitivity) were found to support that the Muara Angke wetland area continues to act as a biological filter for the surrounding megacity. Therefore, it is crucial that existing measures intended to ensure protection for the wetland be reinforced 
and extended where possible to ensure significant ecosystems services to the surrounding area and further afield are not lost. Whilst quantifying the reach and extent of these benefits is beyond the scope of this preliminary research, it is likely to include significant improvements to local soil and water quality, as well as benefits for the health of the Jakarta Bay ecosystem, and regulating the interaction between Jakarta's urban, terrestrial and marine environments more generally. Interestingly, and perhaps unexpectedly, the results recorded at Sites 3 and 4 suggest that the far less extensive green spaces in these areas may already be delivering some measure of ecosystems services to the Ciliwung river, at the very least increasing the input of biological materials.

\section{ACKNOWLEDGEMENTS}

The first author wishes to thank Dr. Robert Francis, project supervisor, whose insight and support was invaluable in undertaking a relatively risky research project in an unknown area and whose guidance in transforming raw data into presentable statistics was particularly key in realizing this research. We appreciate Cendriko Dimas Putra from the Faculty of Biology, Universitas Nasional, Jakarta, and the Jakarta Green Monster, who spent endless hours arranging documents in government institutions, facilitating fieldwork in an incredibly complex urban environment, and helping us collect samples. RUJAK center for Urban Studies, Jakarta, whose ongoing support for all projects about the transformation of Jakarta into a sustainable metropolis remains one of the city's greatest hopes, and whose generosity in allowing the use of their office space and data was invaluable during this time. We acknowledge the government of the Republic of Indonesia, without which this research would not have been possible, particularly the Ministry of Environment and Forestry; Ministry of Research, Technology, and Higher Education, Government of Indonesia.

\section{REFERENCES}

Adakole J, Annune P. 2003. Benthic macroinvertebrates as indicators of environmental quality of an urban stream, Zaria, Northern Nigeria, J Aquat Sci 18 (2): 85-92. DOI: 10.4314/jas.v18i2.19948.

Aerts J, Major D, Bowman M, Dircke P, Marfai M, Abidin H, Ward P, Botzen W, Ali F. 2010. Development of water stress index as a too for the assessment of water stress areas in the Metropolitan Jakarta, 16th Annual International Sustainable Development Research Conference, Hong Kong.

Allen D, Smith K, Darwall W. 2012. The Status and Distribution of Freshwater Biodiversity in Indo-Burma. IUCN, Cambridge.

Anderson N, Sedell J. 1979. Detritus processing by macroinvertebrates in stream ecosystems. Ann Rev Entomol 24 (1): 351-377. DOI: 10.1146/annurev.en.24.010179.002031.

Azrina M, Yap C, Ismail A. R, Ismail A, Tan S. 2006. Anthropogenic impacts on the distribution and biodiversity of benthic macroinvertebrates and water quality of the Langat River, Peninsular Malaysia. Ecotoxicol Environ Saf 64 (3): 337-347. DOI: 10.1016/j.ecoenv.2005.04.003.

Burhanuddin. 1993. A study on mangrove fish at Handeuleum Group and Panaitan Island of Ujung Kulon National Park. Proceeding of Workshop on Mangrove Fisheries and Connections, Ipoh, Malaysia, August 1991.
Cairns J, Prall J. 1993. A History of Biological Monitoring Using Benthos Macroinvertebrates. In: Rosenberg D, Resh V (eds) Freshwater Biomonitoring and Benthic Macroinvertebrates. Chapman and Hall, New York, USA.

Chu H, Chen N, Yeung M, Tam N, Wong Y. 1998. Tidetank system simulating mangrove wetland for removal of nutrients and heavy metals from wastewater. Water Sci Technol 38 (1): 361-368. DOI: 10.2166/wst.1998.0085.

Diaz J, Dowdell S, Stein V. 2013. The effect of anthropogenic inputs on benthic stream invertebrates in a tropical montane stream, Dartmouth. Stud Trop Ecol 23: 52.

Dodson S. 2001. Zooplankton communities of restored depressional wetlands in Wisonsin, USA. Wetlands 21 (2): 292. DOI: 10.1672/0277-5212(2001)021[0292:ZCORDW]2.0.CO;2.

Emere M, Nasiru C. 2008. Macroinvertebrates as indicators of the water quality of an urbanised stream, Kaduna, Nigeria. Nat Sci 7 (1): 1-7.

Farag A, Woodward D, Goldstein J, Brumbaugh W, Meyer J. 1998. Concentrations of metals associated with mining waste in sediments, biofilm, benthic macroinvertebrates, and fish from the Coeur d'Alene River Basin, Idaho. Arch Environ Contam Toxicol 34 (2): 119-127. DOI: $10.1007 / \mathrm{s} 002449900295$.

Ferianita-Fachrul M, Salim MR, Said MIM. 2011. The effect of water quality disturbances on macrozoobenthos communities in Jakarta bay waters, Indonesia. The Fifth IOC/WESTPAC International Scientific Symposium - Ocean Sciences at the Dawn of a New Millenium, Seoul, Republic of Korea.

Firaus R. 2013. Benefits of Green Space for Air Quality Improvement and GHG Emissions Reduction in Jakarta. International Institute of Urban Management, Erasmus University, Rotterdam.

Giesen W, Wulffraat S, Zieren M, Sholten L. 2007. Mangrove Guidebook for South East Asia. Wetlands International/FAO Press, Bangkok, Thailand.

Harmon S. 2008. Effects of pollution on freshwater organisms Water Environ Res 82 (10): 1945-2000. DOI: 10.2175/106143008X328851.

Hartnoll R. 1988. Ecoethology of mangroves, behavioural adaption to intertidal. Life 151: 477-489. DOI: 10.1007/978-1-4899-3737-7_30.

Hodkinson I, Jackson J. 2005. Terrestrial and aquatic invertebrates as bioindicators for environmental monitoring, with particular reference to mountain ecosystems. Environ Manag 35 (5): 649-666. DOI: 10.1007/s00267-004-0211-x.

Hsu M, Selveraj K, Agoramoorthy G. 2007. Taiwan's heavy metal pollution threatens terrestrial biota. Environ Poll 143 (2): 327-334. DOI: 10.1016/j.envpol.2005.11.023.

Ligtvoet W, Hughes R, Wulffraat S. 1996. Recreating mangrove forest near Jakarta, Conserving biodiversity in an urban environment. Land Water Intl 84: 8-11

Lin K, Yo S. 2008. The effect of organic pollution on the abundance of aquatic oligochaetes in an Urban Water Basin, Taiwan. Hydrobiologia 596 (1): 213-223. DOI: 10.1007/s10750-007-9098-x.

Magee P. 1993. Detrital Accumulation and Processing in Wetlands. Fish Wildlife Leaflet 13.3.14. DOI: 10.1007/BF03161297.

Mason C. 2002. Biology of Freshwater Pollution. Pearson, London, UK.

Mastaller M. 1997. Mangroves - The Forgotten Forest Between Land and Sea. Tropical Press, Kuala Lumpur, Malaysia.

Nur Y, Fasi S, Wirjoatmoto N, Han Q. 2001. Towards Wise Coastal Management Practice in a Tropical Megacity - Jakarta. Ocean Coast Manag 44 (5-6): 335-353. DOI: 10.1016/S0964-5691(01)00054-0.

Ogbeibu A, Oribhabor B. 2002. Ecological impact of river impoundment using benthic macroinvertebrates as indicators. Water Res 36 (10): 2427-2436. DOI: 10.1016/S0043-1354(01)00489-4.

Palupi B. 2007. Muara Angke's flora and fauna. The Jakarta Post. http://www.thejakartapost.com/news/2007/08/07/muaraangke039sfloraandfauna.html.

Rosenberg D, Resh V. 1993. Introduction to Freshwater Biomonitoring and Benthic Macroinvertebrates. Chapman and Hall, New York.

Sasekumar A, Chong V, Leh M, D'Cruz R. 1992. Mangroves as a habitat for fish and prawns. Hydrobiologica 247: 195-207. DOI: 10.1007/978-94-017-3288-8_21.

Schläpfer F, Schmid B, Seidl I. 1999. Expert estimates about effects of biodiversity on ecosystem processes and services. Oikos 84: 346-352. DOI: $10.2307 / 3546733$

Sharma R, Rawat J. 2009. Monitoring of aquatic macroinvertebrates as bioindicator for assessing the health of wetlands: A Case Study in the Central Himalayas, India. Ecol Indicat 9 (1): 118-128. DOI: 10.1016/j.ecolind.2008.02.004. 
Supartono J, Haluan MFA, Sondita, Manuwoto. 2016. Jakarta North Coast development impact on fishery activities. Asian J Sci Res 9 (1): 13 23. DOI: 10.3923/ajsr.2016.13.23.

Swari A, Arfiati D, Marsoedi. 2014. Type and abundance of macrozoobenthos as a pollution indicator in Ken Dedes River at Singosari Subdistrict, Malang Regency, East Java, Indonesia. Intl J Engin Sci 3: 43.

Tilley D, Badrinarayanan H, Rosati R, Son J. 2002. Constructed wetlands as recirculation filters in largescale shrimp aquaculture. Aquacult Eng 26 (2): 81-109. DOI: 10.1016/S0144-8609(02)00010-9.

Voshell J. 2002. A Guide to Common Freshwater Invertebrates of North America. The McDonald \& Woodward Publishing Company, Blacksburg, VA
Warwick P. 1993. A new method for detecting pollution effects on marine macrobenthic communities. Mar Biol 92 (4): 557-562.

Weston D. 1990. Quantitative examination of macrozoobenthic community changes along an organic enrichment gradient. Mar Ecol Prog Ser 61 (3): 233-244. DOI: 10.3354/meps061233.

Wong Y, Tam N, Chen G, Ma H. 1997. Response of Aegiceras cornicaltum to synthetic sewage under simulated tidal conditions. Hydrobiologia 352: 89. DOI: 10.1007/978-94-011-5234-1_10.

Ye Y, Tam N, Wong Y. 2001. Livestock wastewater treatment by a mangrove potcultivation system and the effect of salinity on the nutrient removal efficiency. Mar Pollut Bull 42 (6): 512-520. DOI: 10.1016/S0025-326X(00)00196-X. 